\title{
Effectiveness of Fungicide on Soybean Rust in the Southeastern United States: A Meta-Analysis
}

\author{
Mary Delaney ${ }^{1, *}$, Althea A. ArchMiller ${ }^{2}$, Dennis P. Delaney ${ }^{3}$, Alan E. Wilson ${ }^{4}$ (D) and \\ Edward J. Sikora ${ }^{1}$ \\ 1 Department of Entomology and Plant Pathology, Auburn University, Auburn, AL 36849, USA; \\ sikorej@auburn.edu \\ 2 Department of Biology, Concordia College, Moorhead, MN 56560, USA; aarchmil@cord.edu \\ 3 Department of Crop, Soil and Environmental Science, Auburn University, Auburn, AL 36849, USA; \\ delandp@auburn.edu \\ 4 School of Fisheries, Aquaculture and Aquatic Sciences, Auburn University, Auburn, AL 36849, USA; \\ wilson@auburn.edu \\ * Correspondence: delanma@auburn.edu; Tel.: +1-334-703-7579
}

Received: 19 March 2018; Accepted: 23 May 2018; Published: 29 May 2018

\begin{abstract}
Soybean rust (SBR), caused by the fungus Phakopsora pachyrhizi Sydow, has been of concern to soybean (Glycine max Merrill) growers in the southern United States since its introduction in 2004. As this fungus develops, pustules become numerous on the underside of leaves, which then turn yellow and drop prematurely, resulting in fewer pods, and poorly developed seeds. Our objective was to evaluate the efficacy of fungicide use in controlling SBR by conducting a meta-analysis of 61 published and unpublished trials across the southern United States from 2004 to 2014. We analyzed fungicide efficacy based on factors such as specific classes of fungicide, active ingredients, number of fungicide applications, target growth stage upon initial application, level of disease pressure, and year of the study. Fungicides significantly increased yield and 100-seed weight and decreased the severity of SBR. The means of SBR severity, yield, and 100-seed weight in fungicide-treated plants were $9 \%$ ( $95 \%$ confidence interval: $2 \%, 21 \%), 128 \%(121 \%, 135 \%)$, and $121 \%(116 \%, 128 \%)$, respectively, of those calculated in the control plants. By using meta-analysis to analyze fungicide efficacy across multiple field trials, we were able to determine that one application of a strobilurin fungicide when plants were either beginning pod development (R3) or developing seeds (R5) was the most cost-effective approach to controlling SBR and increasing 100-seed weight.
\end{abstract}

Keywords: strobilurin; triazole; fungicide spray program; yield response; sustainable agriculture

\section{Introduction}

Soybean rust (SBR), caused by the fungus Phakopsora pachyrhizi Sydow, produces foliar lesions on soybean (Glycine max Merrill) and other legume hosts, resulting in a reduction in area of leaf regions exhibiting photosynthetic activity. In addition, uredinia formed by SBR rupture the host's epidermis and reduce stomatal regulation of transpiration, causing severe desiccation and premature defoliation [1]. Soybean rust is present globally, first discovered in Japan in 1902. It spread to Asia and Australia by 1984, Africa in the 1990s, and South America in 2001 [2]. Soybean rust causes moderate-to-severe yield losses worldwide [3-6], especially if plants defoliate during the mid-reproductive growth stages of development [3]. For example, SBR-mediated yield losses between $60 \%$ and 100\% were reported in Brazil, Paraguay, and South Africa during the early 2000s [6].

Soybean rust was first reported in the continental United States (US) in November 2004 [7], and has been a recurring problem for soybean growers in the southeastern United States. Yield losses estimated 
at 25\% were first reported from commercial fields in Mississippi in 2009 [8]. In 2012, SBR reduced yield by over $60 \%$ in $>200$ ha of poorly managed soybeans in the southern region of Alabama, whereby fields with the greatest yield losses either received a fungicide application too late, or failed to receive a fungicide spray $[9,10]$. Estimated economic losses were upward of $\$ 135,000$ to farmers who failed to apply a fungicide that year [8,11]. Significant damage from SBR was also observed in Alabama in 2013, where yield losses of up to $40 \%$ were estimated in unprotected or poorly protected soybean fields $[8,10]$. Early detection of SBR, and properly timed fungicide applications are the best methods available to avoid yield loss due to the disease. In addition to SBR, fungicides can reduce damage from other foliar diseases, such as aerial web blight (Rhizoctonia solani), anthracnose (Colletotrichum truncatum), Cercospora leaf blight (Cercospora kikuchii), frogeye leaf spot (Cercopsora sojina), pod and stem blight (Diaporthe phaseolorum var. sojae), and target spot (Corynespora cassiicola) [8]. Currently, a number of foliar fungicides, with varying active ingredients and modes of action, are available for disease management of soybean in the US. However, contextual factors, such as recent environmental conditions, proximity to sources of SBR inocula, cost of available products, and an estimate of the crop yield potential should be considered when determining a fungicide program [12].

In addition to the environmental context, the mode of action or class of a fungicide is also relevant when developing a management plan for SBR. Fungicides most commonly used for SBR management in the US throughout 2013 were typically divided into two classes: quinone outside inhibitors (strobilurins), and demethylation inhibitors (triazoles). Mixing different classes is also commonly practiced. Strobilurins (e.g., azoxystrobin, pyraclostrobin, and trifloxystrobin) are a protectant type of fungicide that prevents fungal pathogens from successfully penetrating host tissue. Strobilurins have the ability to stop both spore germination and host penetration, but have little to no effect once the pathogen has successfully penetrated or colonized the host's plant tissue [13]. Triazole fungicides have protectant and curative activity against fungal pathogens and can inhibit or stop the development of infections that have already occurred. Some triazole fungicides also have a degree of anti-sporulant activity that helps limit the reproductive potential of the fungus. This anti-sporulant activity makes triazole fungicides favorable for initial treatment when SBR is established in a field at low levels. However, triazole fungicides have reduced activity once infections begin to produce spores, which is why fungicides are generally less effective once SBR has become established in a field. Fungicides with a mix of strobilurin and triazole, which can be purchased as a premix or mixed by hand, are effective against spore germination, host penetration, and initial tissue colonization. Other fungicide classes that have been used for SBR management include products in the thiophanate and chloronitrile chemical groups. Pesticide resistance to SBR has not been reported in the United States, although there is evidence of a decrease in the effectiveness of demethylation inhibitors (tebuconizole) in Brazil [6].

Meta-analysis, which is the quantitative synthesis of results across related studies that address a similar hypothesis, has been a common tool in the medical and social sciences since the 1980s [14]. However, the use of meta-analysis in the field of plant pathology is more recent (e.g., the first known plant-pathology meta-analysis was conducted in 1999 [15]). In one study, researchers used meta-analysis to synthesize a series of uniform fungicide trials in Brazil to determine the magnitude of the negative correlation between SBR and yield, and how moderating variables, such as SBR disease pressure, year of study, and whether fungicides were applied before or after flowering, influenced this relationship [16]. The authors found that applying fungicide after flowering (i.e., after the growth stage known as "beginning bloom") significantly reduced yield losses when compared with applying fungicides before flowering. However, Dalla Lana et al. [16] did not examine the effects of differing management scenarios (e.g., classes or ingredients of the fungicides, and the number of applications) on SBR or yield, other than the timing of application relative to flowering. In another related meta-analysis, Scherm et al. [17] focused on the overall efficacy of fungicidal treatments in reducing SBR in Brazil, and to what extent efficacy depended on overall disease pressure, the number of fungicide applications, the amount of disease present at the time of first application, fungicide classes, and specific active 
ingredients. Their results showed a clear difference in efficacy among several active ingredients when used alone or in combination [17].

The objective of this study was to use meta-analysis to synthesize available SBR research reports (published and unpublished) in the southeastern US to test how fungicide active ingredients, fungicide classes, and application timing and frequency affected SBR severity, on the basis of soybean yield and 100-seed weight. We hypothesized that the class of compounds (e.g., strobilurins, triazoles, and products with mixed modes of action), and the active ingredients in the fungicides that were applied would affect fungicide efficacy, while the number of applications, and the soybean growth stage at which the fungicide was applied would affect soybean yield, 100-seed weight, and disease severity.

\section{Materials and Methods}

We identified fungicide trials conducted on soybean for the control of SBR by performing a search of Plant Disease Management Reports, Fungicide and Nematicide Tests, and other related review articles from January 2005 to July 2014 (Table 1). We searched for publications using the key words "Phakopsora pachyrhizi", "fungicide", "Glycine max", and "disease control". We also included data from unpublished fungicide trials that were conducted in Alabama during the 2012-2013 growing seasons (D. Delaney, unpublished; Table 1). Inclusion criteria required that the articles be primary, replicated studies that used foliar application of fungicides, with a minimum of three replications in addition to a control treatment (i.e., no fungicide application). We also limited the time period of studies to 2005 (the first full year SBR was present in the US) through 2014, and the geographical range to five southeastern states (Alabama, Florida, Georgia, Louisiana, and Mississippi), where significant yield losses from SBR were observed in commercial fields and research plots [8].

Table 1. Complete list of references collected for the meta-analysis, including publication type, the year the study was conducted, the state in which the study was conducted, and the total number of entries per study $(n)$. The table is separated into a list of studies used in the meta-analysis, and those collected but not used in the meta-analysis. Full citation information given for each study has been provided in the Appendix A.

\begin{tabular}{|c|c|c|c|c|}
\hline \multicolumn{5}{|l|}{ Studies Used in the Meta-Analysis } \\
\hline Reference & Type $^{1}$ & Study Year & State $^{2}$ & $n$ \\
\hline Delaney and Sikora (2013a) & UP & 2013 & $\mathrm{AL}$ & 12 \\
\hline Delaney et al. (2011) & PDMR & 2010 & AL & 8 \\
\hline Delaney, Sikora, and Delaney (2013a) & PDMR & 2013 & $\mathrm{AL}$ & 9 \\
\hline Delaney, Sikora, and Delaney (2013b) & PDMR & 2013 & AL & 9 \\
\hline Douglas et al., "Fungicides at NFREC," (2008) & PDMR & 2008 & FL & 18 \\
\hline Douglas et al., "Topguard at NFREC," (2008) & PDMR & 2008 & FL & 13 \\
\hline Harmon et al. (2006) & PDMR & 2006 & FL & 12 \\
\hline Kemerait et al., "Attapulgus Trial 3,” (2006) & PDMR & 2006 & GA & 5 \\
\hline Lawrence et al. (2009) & PDMR & 2008 & $\mathrm{AL}$ & 9 \\
\hline Lawrence et al. (2013) & PDMR & 2013 & $\mathrm{AL}$ & 5 \\
\hline Lawrence et al., “Absolute, Folicur and Stratego,”(2007) & PDMR & 2006 & AL & 3 \\
\hline Lawrence et al., "Absolute," (2006) & FNT & 2005 & $\mathrm{AL}$ & 6 \\
\hline Lawrence et al., “LEM17,” (2007) & PDMR & 2007 & AL & 6 \\
\hline Lawrence et al., "Punch 2005," (2006) & FNT & 2005 & $\mathrm{AL}$ & 6 \\
\hline Lawrence et al., "Punch and Charisma 2006," (2006) & PDMR & 2006 & $\mathrm{AL}$ & 10 \\
\hline Lawrence et al., "Selected fungicides," (2007) & PDMR & 2006 & AL & 11 \\
\hline Lawrence et al., "Soybean rust fungicide," (2008) & PDMR & 2008 & AL & 13 \\
\hline Lawrence et al., "Topsin," (2007) & PDMR & 2007 & AL & 7 \\
\hline Lawrence et al., “Topsin,” (2008) & PDMR & 2007 & $\mathrm{AL}$ & 7 \\
\hline Mueller et al., "Cerexagri,” (2008) & PDMR & 2006 & FL & 11 \\
\hline Mueller et al., "Cheminova," (2006) & PDMR & 2006 & FL & 17 \\
\hline Mueller et al., “Dow fungicides,"(2008) & PDMR & 2006 & FL & 6 \\
\hline Mueller et al., “Fungicides for soybean rust,” (2008) & PDMR & 2006 & FL & 15 \\
\hline Mueller et al., "Valent," (2008) & PDMR & 2006 & FL & 4 \\
\hline
\end{tabular}


Table 1. Cont.

\begin{tabular}{|c|c|c|c|c|}
\hline Mueller, Marois, and Wright (2008a) & PDMR & 2007 & FL & 3 \\
\hline Mueller, Marois, and Wright (2008b) & PDMR & 2007 & FL & 9 \\
\hline Mueller, Miles, and Hartman (2008) & PDMR & 2006 & GA & 15 \\
\hline Mueller, Miles, and Hartman et al. (2008) & PDMR & 2006 & FL & 23 \\
\hline Padgett and Purvis (2007) & PDMR & 2005 & LA & 9 \\
\hline Price et al. (2013) & PDMR & 2012 & LA & 12 \\
\hline Sikora et al. (2006) & PDMR & 2006 & $\mathrm{AL}$ & 12 \\
\hline Sikora et al. (2009) & PRP & 2007 & $\mathrm{AL}$ & 12 \\
\hline Sikora, Delaney, and Delaney (2013a) & PDMR & 2013 & $\mathrm{AL}$ & 4 \\
\hline Sikora et al., "Ballad," (2005) & FNT & 2006 & $\mathrm{AL}$ & 7 \\
\hline \multicolumn{5}{|l|}{ Studies Not Used in the Meta-Analysis } \\
\hline Reference $^{3}$ & Type & Study Year & State & $n$ \\
\hline Allen (2011a) & PDMR & 2010 & MS & 8 \\
\hline Allen (2011b) & PDMR & 2010 & MS & 7 \\
\hline Allen (2013a) & PDMR & 2011 & MS & 5 \\
\hline Allen $(2013 b)$ & PDMR & 2011 & MS & 5 \\
\hline Delaney and Sikora (2009) & UP & 2009 & $\mathrm{AL}$ & 13 \\
\hline Delaney and Sikora (2013b) & UP & 2013 & $\mathrm{AL}$ & 2 \\
\hline Delaney and Sikora (2013c) & UP & 2013 & $\mathrm{AL}$ & 2 \\
\hline Delaney and Sikora (2013d) & UP & 2013 & $\mathrm{AL}$ & 3 \\
\hline Delaney and Sikora (2013e) & UP & 2013 & $\mathrm{AL}$ & 2 \\
\hline Delaney et al. (2012) & PDMR & 2011 & $\mathrm{AL}$ & 12 \\
\hline Delaney et al., "Belle Mina," (2010) & UP & 2010 & $\mathrm{AL}$ & 8 \\
\hline Delaney et al., "Shorter" (2010) & UP & 2010 & $\mathrm{AL}$ & 8 \\
\hline Douglas et al. (2009) & PDMR & 2009 & FL & 11 \\
\hline Kemerait and Sconyers (2006) & PDMR & 2006 & GA & 12 \\
\hline Kemerait et al., "Attapulgus Valent," (2006) & PDMR & 2006 & GA & 15 \\
\hline Kemerait, Jost, and Sconyers (2005) & FNT & 2005 & GA & 8 \\
\hline Kemerait, Sconyers, and Jost (2006) & PDMR & 2006 & GA & 10 \\
\hline Kemerait, Sconyers, and Mills (2006) & PDMR & 2006 & GA & 7 \\
\hline Mueller et al., "Fungicides and adjuvants," (2006) & PDMR & 2006 & FL & 6 \\
\hline O'Brien et al., “NFREC 2012,” (2013) & PDMR & 2012 & FL & 7 \\
\hline O'Brien, George, Douglas, et al. (2013) & PDMR & 2013 & FL & 13 \\
\hline Padgett and Purvis (2005b) & PDMR & 2005 & LA & 15 \\
\hline Padgett and Purvis. (2005a) & PDMR & 2005 & LA & 15 \\
\hline Schneider et al. (2006) & PDMR & 2006 & LA & 23 \\
\hline Sikora et al. (2012) & PDMR & 2011 & $\mathrm{AL}$ & 4 \\
\hline Sikora, Delaney, and Delaney (2013b) ${ }^{4}$ & PDMR & 2013 & $\mathrm{AL}$ & 4 \\
\hline Sikora et al., “Asian soybean rust,” (2005) & FNT & 2005 & AL & 13 \\
\hline
\end{tabular}

${ }^{1}$ PDMR = Plant Disease Management Report; UP = unpublished study; FNT = Fungicide and Nematicide Test; and PRP = peer-reviewed publication; ${ }^{2} \mathrm{AL}=$ Alabama; FL = Florida; GA = Georgia; LA = Lousiana; and MS $=$ Mississippi; ${ }^{3}$ References omitted from analysis because no rust severity was reported unless otherwise noted; ${ }^{4}$ Reference was omitted because mean rust severity from untreated control plants was $<5 \%$.

We recorded data from each study that met the inclusion criteria, including a unique study identifier, a study location (state), a fungicide trade name, active ingredients, a fungicide class, a number of applications, a growth stage of the soybean plants at each application, a study year, a number of experimental replicates, an amount of fungicide applied, and mean values of SBR severity, yield, and 100-seed weight in treated and control plants. When applicable, we converted yield from bushels per acre to $\mathrm{kg} / \mathrm{ha}$ for analysis. The level of SBR infection at the time of fungicide application was not reported in any of the fungicide trials; however, we used mean SBR severity in the untreated control plants as checks to quantify the degree to which disease pressure was present. After collecting data, we further excluded data from any studies that did not report SBR severity, or where the mean severity in untreated control plants was $<5 \%$, following Scherm et al. [17] (Table 1). We only considered a moderator category for analysis when there were at least 15 entries from at least five different studies. 
Disease severity was either reported directly in percentages, or on varying scales; thus, we transformed all disease-severity scales into percentages for consistent cross-study comparisons. Studies published with the $0-8$ scale represented disease severity as follows: 0 to $1=0-2.5 \%,>1$ to $2=2.5-5 \%,>2$ to $3=5-10 \%,>3$ to $4=10-15 \%$, $>4$ to $5=15-25 \%,>5$ to $6=25-35 \%,>6$ to $7=35-67.5 \%$, and $>7$ to $8=67.5-100 \%$ (e.g., see meta-analysis, reference Sikora and Delaney 2013a). Studies that published SBR values on the 0-10 scale represented disease severity as follows: 1 to $3=0-2.5 \%,>3$ to $4=2.5-5 \%$, $>4$ to $5=5-10 \%,>5$ to $6=10-15 \%,>6$ to $7=15-25 \%,>7$ to $8=25-35 \%,>8$ to $9=35-67.5 \%$, and $>9$ to $10=67.5-100 \%$ (e.g., see meta-analysis, reference Padgett and Purvis 2005b). We inputted disease severity as a percentage, based on a constant rate of change between scalar values [18]. For instance, if mean SBR severity was given as 4.5 out of 10 , we calculated the SBR severity as $7.5 \%$ (i.e., 0.5 of the distance between a value of 4 and a value of 5).

All data analyses were conducted with the metafor package in the $\mathrm{R}$ software $[19,20]$. We calculated the $\log$ response ratio, $\ln \left(R_{i}\right)$, from each treatment-specific entry $i$ from each study as follows:

$$
\ln \left(R_{i}\right)=\ln \left(\frac{y_{t i}}{y_{c i}}\right)
$$

where $y_{t i}$ is the mean value from the treated plants, and $y_{c i}$ is the mean value from the control plants. All entries in the meta-analysis were weighted by the level of disease pressure, as defined by the mean SBR severity in untreated control plants [17]. We analyzed mean log response ratios using random-effects models with a restricted-maximum-likelihood estimator and evaluated overall means and 95\% confidence intervals (CIs) with cluster-level (i.e., study-level) bootstrapping. We used bootstrapping because: (1) we assumed that log response ratios derived from a common study would be more related than those from another study, and (2) values representing error (e.g., standard error, or variance) were not reported in the published fungicide trials [21,22]. Specifically, we randomly selected $N$ studies with replacement to create a new dataset [22], where $N$ was the total number of studies in the SBR severity, yield, and 100-seed-weight datasets. We then calculated the weighted-mean effect size (using the rma.uni function from metafor) for each new dataset, and stored the values of weighted-mean effect size. We repeated these steps of randomly sampling data from studies, conducting meta-analysis, and storing values of mean effect size a total of 5,000 times each for SBR severity, yield, and 100-seed-weight datasets. We reported the means and 95\% confidence intervals as the $50 \%$, and the $2.5 \%$ and $97.5 \%$ quantiles, respectively, which were then transformed back into raw response ratios for reporting (rather than on the log scale). Positive (i.e., desired) effects of fungicide treatment when compared with control groups were indicated by response ratios $<1$ for disease severity, and by response ratios $>1$ for yield and 100-seed weight. The complete dataset, and the R code used for data processing, analysis, and figure production were published in the Data Repository for the University of Minnesota (http:/ / doi.org/10.13020/D62P4F) [23].

\section{Results}

The data used in this meta-analysis were extracted from 61 studies, including 47 Plant Disease Management Reports, five Fungicide and Nematicide Tests, one peer-reviewed publication, and eight unpublished studies, conducted between 2005 and 2013 (Table 1). The majority of fungicide trials we identified were conducted in Alabama (30), followed by Florida (15), Georgia (7), Louisiana (5), and Mississippi (4). We excluded 27 fungicide trials from analysis because 26 did not report SBR severity, while one had too low a level of disease pressure (i.e., control SBR severity $<5 \%$; Table 1). We retained 18 Alabama fungicide trials (148 entries), 11 Florida fungicide trials (131 entries), two Georgia fungicide trials ( 20 entries), and two Louisiana fungicide trials (21 entries) for analysis (Table 1).

Across all the studies used in the meta-analysis, the means (standard deviation, SD) of SBR severity were $24.4 \%$ (29.0\%) in treated plants, and $60.2 \%$ (33.4\%) in control plants. Over $40 \%$ of the studies had SBR severity in treated plants of $\leq 5 \%$, whereas over half of the untreated control plants 
had high disease pressure (i.e., SBR severity of 70\%). Mean (SD) yields were 3731 (1166) kg/ha and 3064 $(1000) \mathrm{kg} / \mathrm{ha}$ in treated plants and control plants, respectively. The means (SD) of 100-seed weights across all studies were $11.9 \mathrm{~g}(6.2 \mathrm{~g})$ and $10.5 \mathrm{~g}(5.6 \mathrm{~g})$ in treated plants and control plants, respectively.

Across all the fungicide trials analyzed, the weighted, bootstrapped means (95\% CIs) of the response ratios were $0.09(0.02,0.21), 1.28(1.21,1.35)$, and $1.21(1.16,1.28)$ for SBR-severity, yield, and 100-seed-weight analyses, respectively (Table 2 and Figure 1). These response ratios indicated that across all studies, fungicide application decreased SBR severity, and increased yield and 100 -seed weight relative to the untreated control plants. The average $(95 \% \mathrm{CIs})$ estimates of residual heterogeneity $\left(\tau^{2}\right)$ were $14.6(6.4,22.4), 0.02(0.00,0.04)$, and $0.0(0.00,0.01)$ for SBR-severity, yield, and 100-seed-weight analyses, respectively. There was not a strong overall relationship between weighted, bootstrapped means of response ratios for SBR severity, when compared with those of yield or 100-seed weight; however, there was an overall positive relationship between the weighted, bootstrapped means of response ratios for yield and 100-seed weight across moderator categories (Figure 1). All weighted, bootstrapped means of response ratios clustered around the overall mean values, except for the mean response ratio for yield from studies conducted in 2013, which had a relatively weak yield response given the average SBR-severity response (Figure 1).

Table 2. Results of the meta-analysis. Weighted, bootstrapped means, standard deviations (SDs), $95 \%$ confidence intervals (CIs), and sample sizes ( $\mathrm{N}=$ the number of studies, and $\mathrm{n}=$ the number of treatment-specific entries) of the response ratios for the effect of fungicide application on soybean rust (SBR), yield, and 100-seed weight across all studies (overall), and for specific moderator levels. Statistics were only reported for moderator level categories used in the analysis (i.e., those with at least 15 records from at least five different studies).

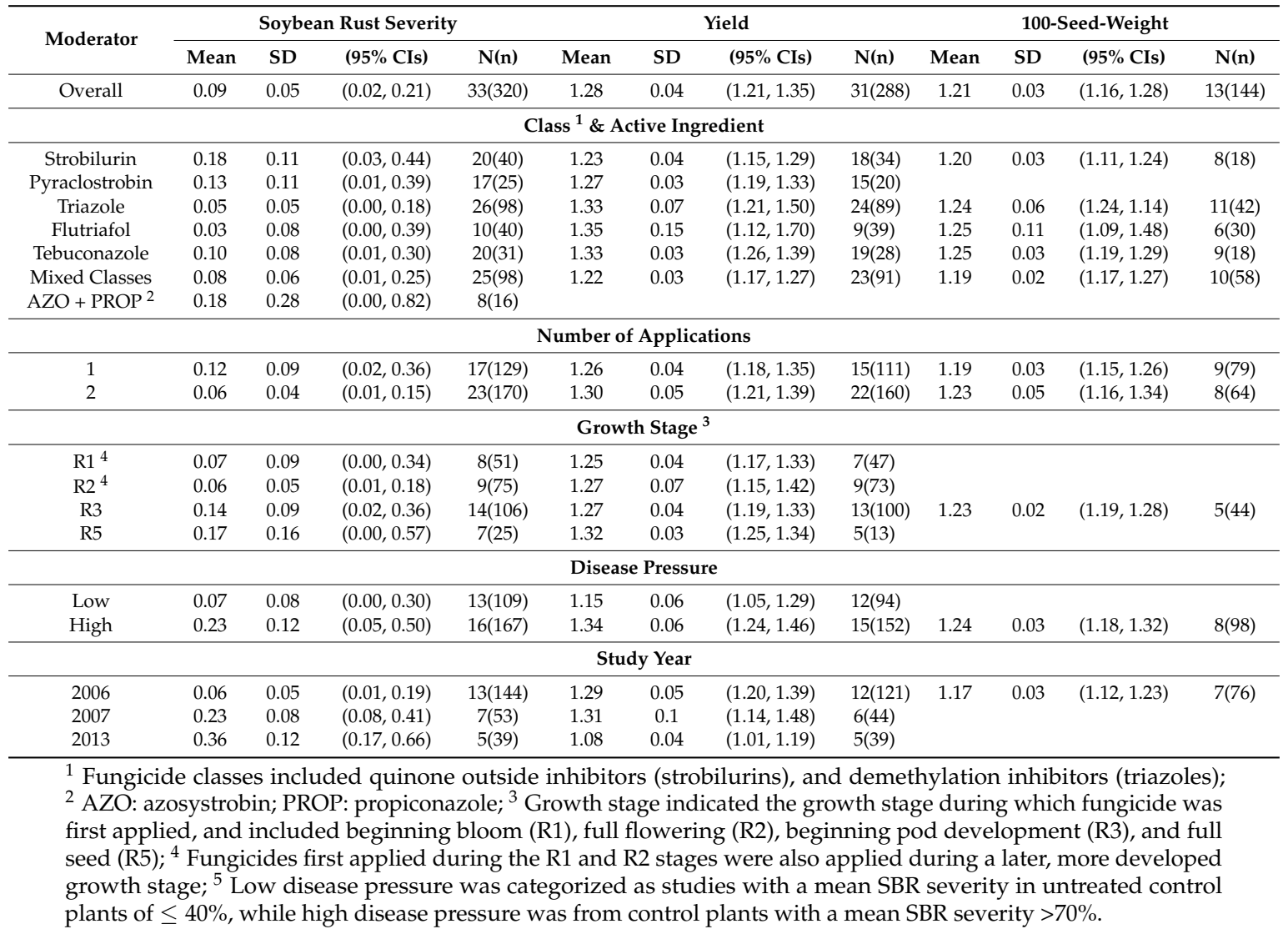



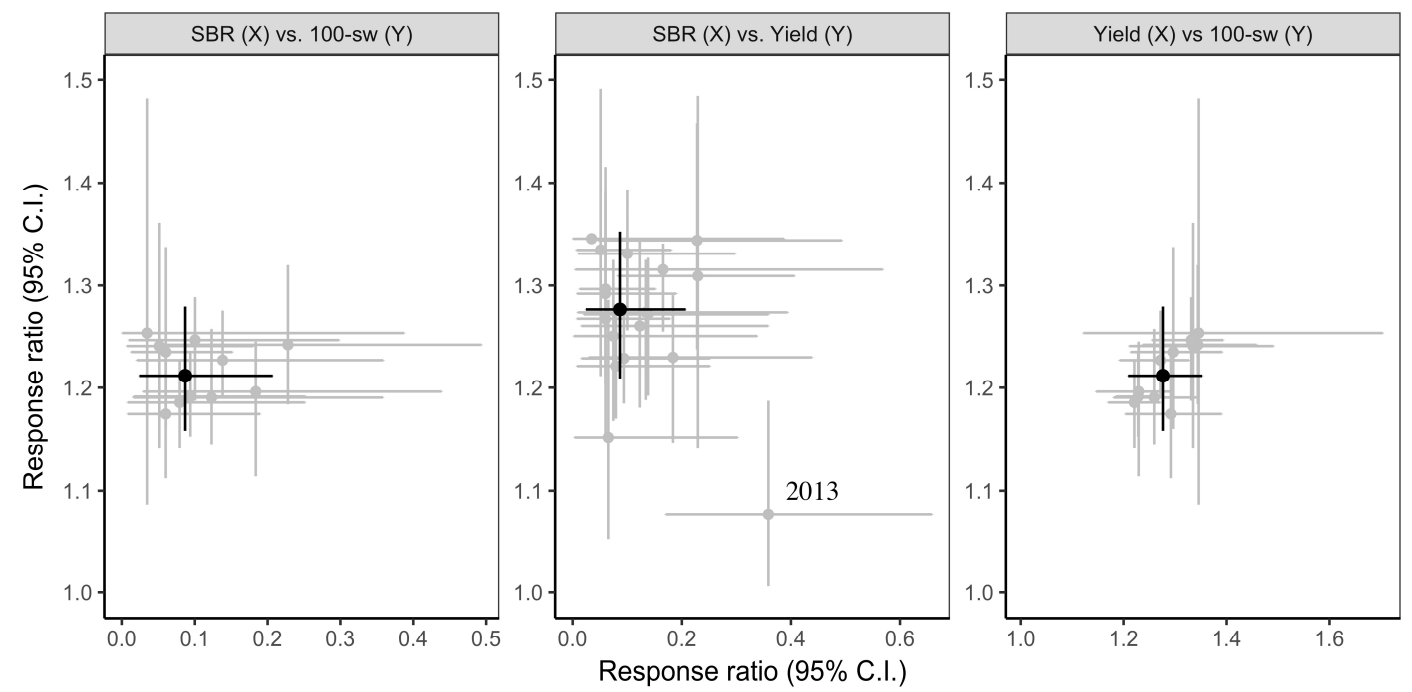

Figure 1. Weighted, bootstrapped means of response ratios for the effect of fungicide application on soybean rust (SBR) severity versus 100-seed weight (SBR vs. 100-sw), SBR severity versus yield (SBR vs. Yield), and yield versus 100-seed weight (Yield vs. 100-sw) for different moderator classes (grey), and for the mean effect across all studies (black). We only analyzed moderator level categories with at least 15 individual entries from at least five different studies. Error bars are 95\% confidence intervals (CIs). The results from 2013 fungicide trials are highlighted on the SBR vs. Yield plot; see text for details.

Although we only had enough studies and study entries to analyze the mean effects of two fungicide classes, including quinone outside inhibitors (strobilurins), and demethylation inhibitors (triazoles); and four active ingredients, including pyraclostrobin, flutriafol, tebuconazole, and mixed active ingredients, we detected significant decreases in SBR severity, and increases in yield and 100-seed weight, regardless of class or active ingredient (Figure 2, Table 2 and Table S1).
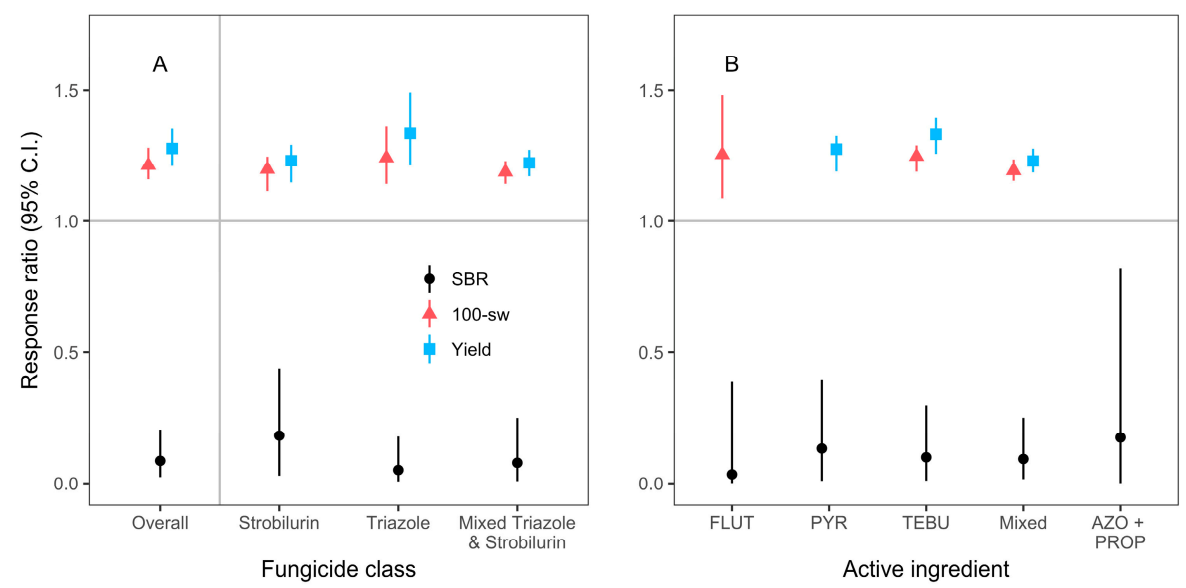

Figure 2. Weighted, bootstrapped means of response ratios for the effect of fungicide application on SBR severity (black circles), yield (blue squares), and 100-seed weight (red triangles) across all studies (Overall, A), for quinone outside inhibitors (strobilurins) and demethylation inhibitors (triazoles) classes of fungicide, including those with mixed triazole and strobilurin classes (A); and for each active ingredient category, including those with mixed active ingredients (Mixed, B). Active ingredients included flutriafol (FLUT), pyraclostrobin (PYR), tebuconazole (TEBU), and a mixture of azoxystrobin (AZO) and propinconazole (PROP). We only analyzed moderator level categories with at least 15 individual entries from at least five different studies. Sample sizes are listed in Table 2. Error bars are $95 \%$ confidence intervals. 
Although fungicides were applied anywhere from one to five times, we only had sample sizes large enough to merit meta-analysis of effects when fungicides were applied one or two times (Figure 3, Table 2 and Table S2). Fungicides were first applied during five different growth stages varying from vegetative stage $(\mathrm{V})$ through to beginning seed (R5), but we only had enough studies to analyze mean effects when fungicides were initially applied to plants that were in first bloom (R1), full flowering (R2), beginning pod development (R3), and full seed (R5) growth stages (Figure 3 and Table 2). For the studies with fungicides applied during the R1 and R2 stages, the investigators also applied fungicides a second time during a more developmentally advanced growth stage (i.e., two total applications). The weighted, bootstrapped means of response ratios were significantly below 1.0 for SBR severity, and above 1.0 for yield and 100-seed weight, thus signifying fungicide efficacy regardless of the number of applications, or the growth stage at the time of initial fungicide application (Figure 3 and Table 2). Disease pressure, measured by mean SBR severity in untreated control plants, was most often at low $(\leq 40 \%)$ or high $(>70 \%)$ levels, with not enough medium-disease-pressure studies to conduct a sub-group meta-analysis for medium disease pressure. There was an indication that the weighted, bootstrapped means of response ratios for yield were higher when disease pressure was high, relative to low; however, a weak, opposite trend was detected for SBR severity (Figure 3 and Table 2).
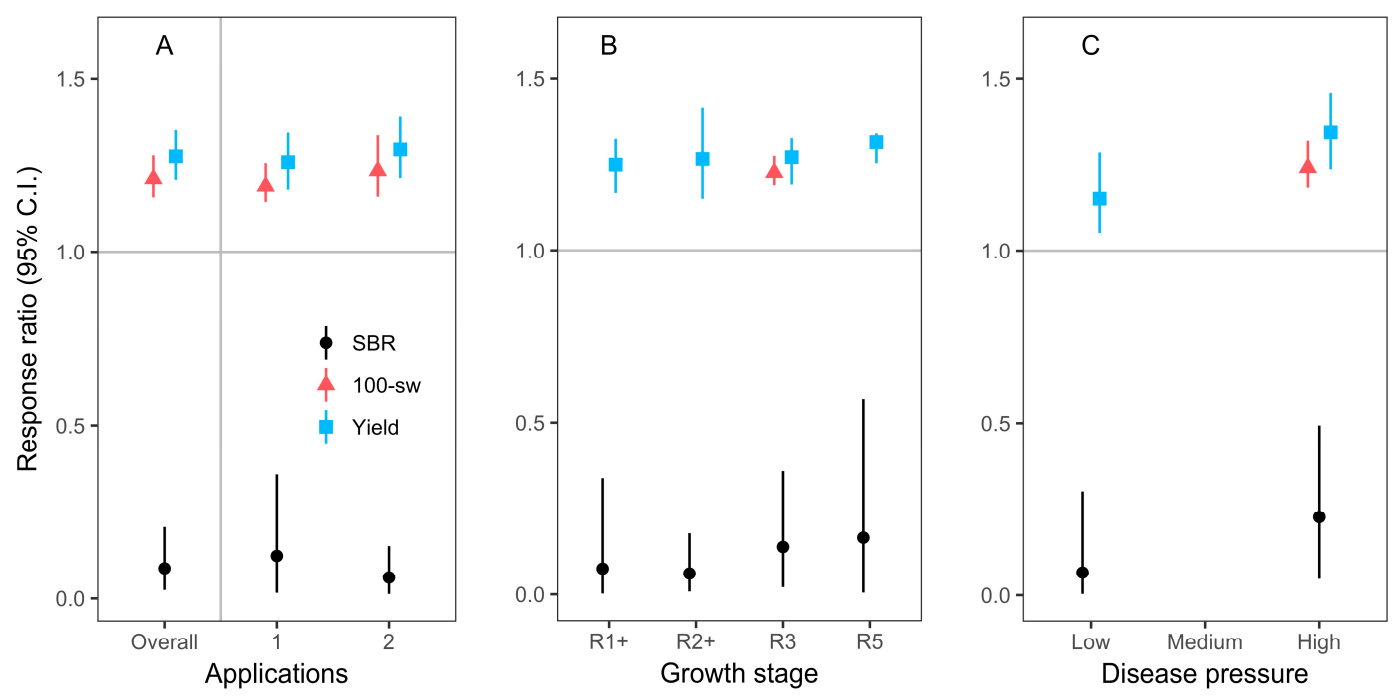

Figure 3. Weighted, bootstrapped means of response ratios for the effect of fungicide application on SBR severity (black circles), yield (blue squares), and 100-seed weight (red triangles) across all studies (Overall, A), for studies with 1 or 2 applications of fungicide (A), for studies where the fungicide was initially applied during beginning bloom (R1+), full flowering (R2+), beginning pod development (R3), and beginning seed (R5) (B); and for varying degrees of disease pressure (C). The plus signs (+) signify that fungicides initially applied during R1 and R2 stages were also applied a second time during a later growth stage. Low disease pressure was categorized as studies with a mean SBR severity in untreated control plants of $\leq 40 \%$, while high disease pressure was from control plants with a mean SBR severity $>70 \%$. We only analyzed moderator level categories with at least 15 individual entries from at least five different studies. Sample sizes are listed in Table 2. Error bars are 95\% confidence intervals.

The majority of studies were conducted in 2006, 2007, and 2013 (Table 1, Table 2 and Table S2). There were fewer studies between 2008 and 2012 to include in this analysis, partly due to the lack of significant development of SBR in previous years, resulting in fewer industry-funded fungicide trials in the southeast region during this period. Also, severe droughts during the growing season in 2010 and 2011 in the southeastern US resulted in minimal SBR pressure in the states typically conducting SBR studies [24]. Our meta-analysis results indicated that fungicides reduced SBR severity in treated plants relative to untreated controls (i.e., response ratio $<1.0$ ), regardless of the year of the study 
(Figure 4 and Table 2). Likewise, the weighted, bootstrapped means, and 95\% confidence intervals of response ratios for yield and 100-seed weight were above 1.0, indicating fungicide efficacy regardless of year (Figure 4 and Table 2). However, there was a trend indicating that the efficacy of fungicide in controlling SBR severity, or increasing yield was lower in 2013, when compared with 2006 or 2007 (Figure 4 and Table 2).

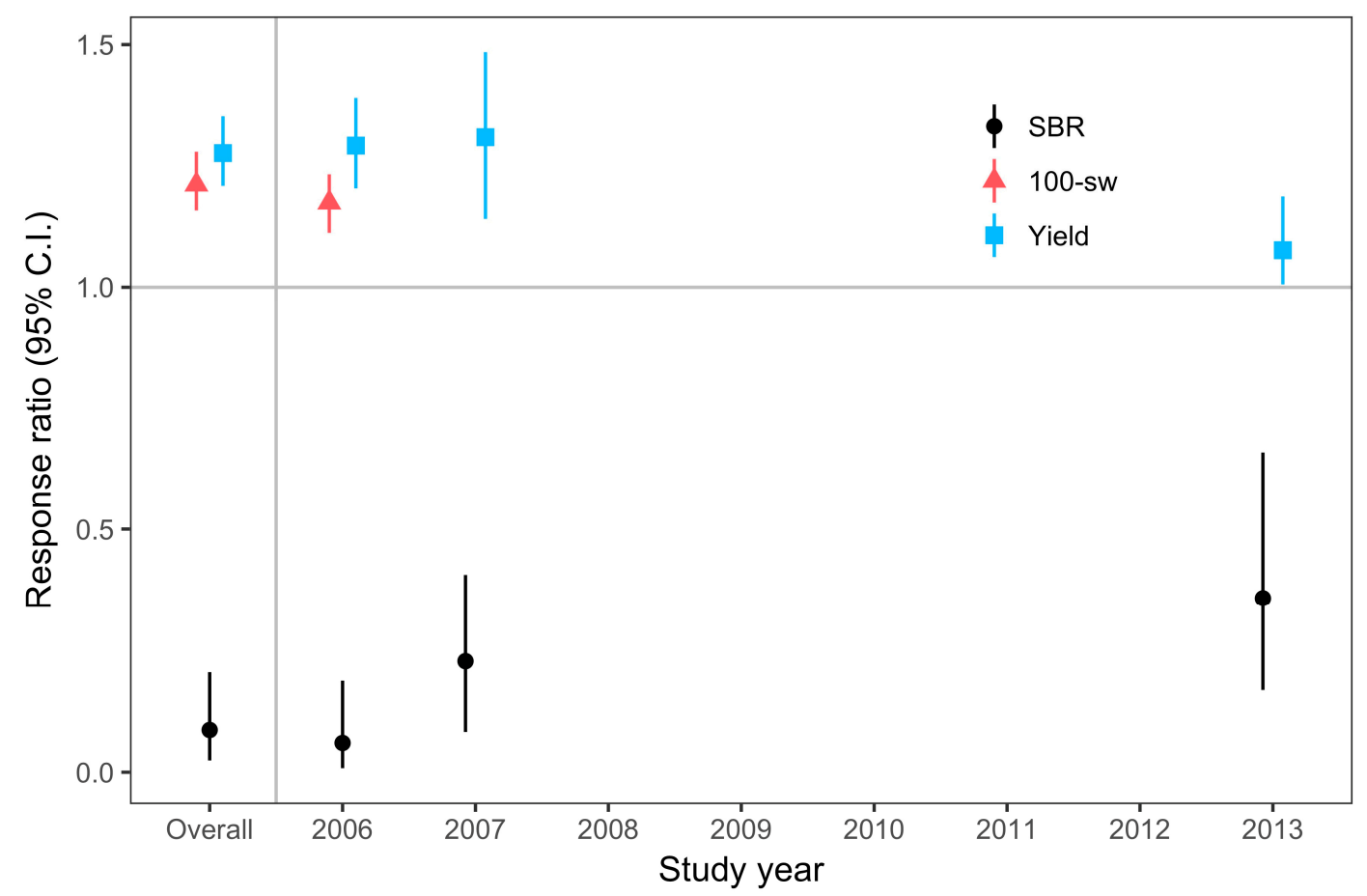

Figure 4. Weighted, bootstrapped means of response ratios for the effect of fungicide application on SBR (black circles), yield (blue squares), and 100-seed weight (red triangles) across all studies (Overall), and for the years in which the studies were conducted. We only analyzed moderator level categories with at least 15 individual entries from at least 5 different studies. Sample sizes are listed in Table 2. Error bars are $95 \%$ confidence intervals.

\section{Discussion}

Meta-analysis provided an opportunity to determine the efficacy of fungicides in treating SBR in the southeastern United States. Specifically, we used meta-analysis to jointly analyze results, from both published literature and unpublished field-study reports, and explore the specific types of fungicides and their application conditions which maximize potency. As of 2018, 23 states in the continental US have reported the presence of SBR [25], although no economic loss was reported in states adjacent to our study. Across all studies, we found that fungicide application corresponded with lower SBR severity, and higher yield and 100-seed weight in treated plants, when compared with untreated control plants. While no single class of fungicide or active ingredient stood out as being the most effective, there was some evidence that triazoles reduced SBR, and increased yield and 100-seed weight, better than strobilurins or even mixtures of both. Scherm et al. [17] also found that triazoles performed significantly better in controlling SBR severity and increasing yield. This is likely due to the fact that triazoles generally show more systemic movement within a plant, and have activity against later stages in the pathogen's life cycle, allowing triazoles to stop or inhibit the development of SBR infections that have already occurred $[13,17]$.

Previous studies suggested that fungicide applications prior to bloom were not economical for SBR management [3], and that applying fungicides after flowering reduced the level of yield loss of 
soybeans, relative to earlier single applications in Brazil [16]. In general, farmers should consider an initial fungicide application when the crop is between bloom and full seed (R6), and when SBR is detected in the immediate area, while environmental conditions favor development and spread of the pathogen. Our results supported this conclusion, indicating somewhat lower response ratios for fungicides applied in R1 and R2, when compared with those applied in R3 or R5. Although two applications of fungicide demonstrated a slightly greater effect on SBR severity, yield, and 100-seed weight, one application also caused significant and positive changes in these metrics. A two-fungicide sequential spray program is relatively expensive, although it may be necessary and economical in instances of severe SBR pressure [12]. In contrast to the uniform fungicide trials synthesized in the Brazilian study [16], we were unable to report on how SBR severity or yield was affected by the disease pressure present at the time of application. However, similar to Scherm et al. [17], we found that, at high levels of disease pressure, yield responded more positively to fungicide applications than did SBR severity. The trend indicating a lower efficacy of fungicide in controlling SBR severity or increasing yield in 2013, when compared with 2006 or 2007, was determined to be a result of SBR being present in test plots prior to the application of fungicide treatments in that particular year in Alabama.

Meta-analysis results should also be tested for sensitivity to any individual studies, or so as to determine if there is a strong time-lag bias present [26]. There was some evidence of time-lag bias, which is a bias resulting from effect sizes that change over time. Time-lag bias is common in ecology and can occur when studies with less significant results are published at a slower rate than those with strongly significant results [27]. This specific reason for time-lag bias was unlikely in this study because we compiled data from both published studies and unpublished field reports, with study years ranging from 2005 to 2013 (Tables 1 and 2).

Meta-analysis facilitates the statistical synthesis of results from studies across a wide range of fields; however, many assumptions should be met to assure a fair and unbiased meta-analysis [26,28]. A lack of severe publication bias, which is a bias resulting from the meta-analysis of a non-inclusive or incomplete dataset, is one the most common assumptions in meta-analysis [29]. Publication bias can occur when studies are missing from a meta-analysis dataset because they were neither published nor made available, nor found during the literature search, nor explicitly included in the dataset $[26,30]$. We attempted to minimize publication bias in this study by including every study we discovered through the literature search that fit our inclusion requirements, and by including many unpublished field reports. Because measurements of uncertainty are not routinely reported in Plant Disease Management Reports (PDMRs) or Fungicide and Nematicide Tests (FNTs), our analysis was limited to cluster-level bootstrapping, restricting the categories that we could analyze to those with rather large sample sizes ( $5+$ studies with $15+$ entries). Thus, we recommend that future fungicide trials that focus on testing moderator categories that we were unable to assess (e.g., azoxystrobin fungicides applied individually) will have the largest impact on our understanding of fungicide efficacy in controlling SBR in the southeastern United States.

Supplementary Materials: The following are available online at http:/ /www.mdpi.com/2071-1050/10/6/1784/ s1, Table S1: Abbreviations and full names of fungicide active ingredients sorted by fungicide class. We report the number of studies $(\mathrm{N})$ and the number of treatment-specific entries (n) for each category from the soybean rust severity (SBR), yield, and 100-seed-weight $(100 \mathrm{sw})$ data sets. Studies sizes are only reported for those moderator level categories used in the analysis (i.e.,those with at least 15 records from at least 5 different studies), Table S2: Moderator categories and levels used in the meta-analysis. We report the number of studies (N) and the number of treatment-specific entries (n) for each category from the soybean rust severity (SBR), yield, and 100-seed-weight $(100 \mathrm{sw})$ data sets. Studies sizes are only reported for those moderator level categories used in the analysis (i.e., those with at least 15 records from at least 5 different studies).

Author Contributions: M.D. and A.W. conceived and designed the experiments; M.D. and D.D. collected the meta-analysis source data; A.A. and A.W. analyzed the data; M.D., E.S., A.A. and A.W. wrote the paper.

Funding: This research received no external funding

Acknowledgments: This project was supported by the Alabama Agricultural Experiment Station and the Hatch Program of the National Institute of Food and Agriculture, U.S. Department of Agriculture. 
Conflicts of Interest: The authors declare no conflict of interest.

\section{Appendix}

List of all publications used in the meta-analysis:

Allen TW. 2011a. Evaluation of foliar fungicide applications to prevent yield loss from aerial web blight in Mississippi, 2010a. Plant Dis. Manag. Rep. 5:FC120. Online publication. doi:10.1094/PDMR05.

Allen TW. 2011b. Evaluation of foliar fungicide applications to prevent yield loss from aerial web blight in Mississippi, 2010b. Plant Dis. Manag. Rep. 5:FC119. Online publication. doi:10.1094/PDMR05.

Allen TW. 2013a. Evaluation of foliar fungicide application to prevent yield loss from aerial web blight in Mississippi, 2011a. Plant Dis. Manag. Rep. 7:FC135. Online publication. doi:10.1094/PDMR07.

Allen TW. 2013b. Evaluation of foliar fungicide application to prevent yield loss from aerial web blight in Mississippi, 2011b. Plant Dis. Manag. Rep. 7:FC134. Online publication. doi:10.1094/PDMR07.

Delaney DP, Sikora EJ. 2009. Triazole fungicides for soybean rust. Unpublished data.

Delaney DP, Sikora EJ. 2013a. Evaluation of foliar applications of triazoles for control of soybean rust, 2013. Unpublished data.

Delaney DP, and Sikora EJ. 2013b. Large-scale fungicide trial Brewton, AL. 2013. Unpublished data.

Delaney DP, Sikora EJ. 2013c. Large-scale fungicide trial EV Smith, AL. 2013. Unpublished data.

Delaney DP, Sikora EJ. 2013d. Large-scale fungicide trial GCREC, AL. 2013. Unpublished data.

Delaney DP, Sikora, EJ. 2013e. Large-scale fungicide trial SMREC, AL 2013 Unpublished data.

Delaney DP, Sikora EJ, Delaney MA. 2013a. Evaluation of fungicides for control of soybean rust. Plant Dis. Manag. Rep. 9:FC145. Online publication. doi:10.1094/PDMR09

Delaney DP, Sikora EJ, Delaney MA. 2013b. Evaluation of fungicides for control of soybean rust and target spot, 2013. Plant Dis. Manag. Rep. 9:FC146. Online publication. doi:10.1094/PDMR09.

Delaney DP, Sikora EJ, Lawrence K, Delaney M. 2012. Evaluation of fungicides for control of Cercospora leaf blight of soybean. 2011. Plant Dis. Manag. Rep. Online publication. doi:10.1094/PDMR06.

Delaney DP, Sikora EJ, Lawrence K, Delaney M., Norris BE, Harkins D. 2011. Evaluation of fungicides for control of aerial web blight on soybean in Alabama, 2010. Plant Dis. Manag. Rep. Online publication. doi:10.1094/PDMR05.

Delaney, DP, Sikora EJ, Lawrence KS, Norris BE, Harkins D. 2010. Strobilurin fungicide greening effects on soybeans at Belle Mina, 2010. Unpublished data.

Delaney DP, Sikora EJ, Lawrence KS, and Scott, S. 2010. Strobilurin fungicide greening effects on soybeans at Shorter, 2010. Unpublished data.

Douglas MH, Obrien GK, Marois J.J, Wright DL. 2008. Evaluation of fungicides for the control of soybean rust at the NFREC, Quincy, FL, 2008. Plant Dis. Manag. Rep. 3:FC111. Online publication. doi:10.1094/PDMR02.

Douglas MH, Obrien GK, Marois JJ, Wright DL. 2008. Evaluation of Topguard fungicide for the control of soybean rust at the NFREC, Quincy, FL, 2008. Plant Dis. Manag. Rep. 3:FC113. Online publication. doi:10.1094/PDMR02.

Douglas MH, Obrien GK, Marois, JJ, Wright DL. 2009. Evaluation of fungicides for the control of soybean rust at the NFREC, Quincy, FL, 2009. Plant Dis. Manag. Rep. 4:FC026. Online publication. doi:10.1094/PDMR03.

Harmon PF, Semer CR, Harmon CL, McGovern RJ. 2006. Evaluation of fungicides and Roundup for control of Asian soybean rust in Florida, 2006. Plant Dis. Manag. Rep. 1:FC034. Online publication. doi:10.1094/FN61.

Kemerait EC, Jost PH, Sconyers LE. 2005. Evaluation of fungicides for control of Asian soybean rust in Lang Farm (Trial 1), Georgia, 2005. Fungicide and Nematicide Tests. Vol 61:074.

Kemerait Jr RC, Sconyers LE. 2006. Evaluation of fungicides for control of Asian soybean rust in Moultrie (Trial 1-SSDW Study), Georgia, 2006. Plant Dis. Manag. Rep. 1:FC081. Online publication. doi:10.1094/FN61. 
Kemerait Jr. RC, Sconyers LE, Jost PH. 2006. Evaluation of fungicides for control of Asian soybean rust in Tifton (RDC Trial), Georgia, 2006. Plant Dis. Manag. Rep. 1:FC083. Online publication. doi:10.1094/FN61.

Kemerait, Jr. RC, Sconyers LE, Jost PH, Mills WA. 2006. Evaluation of fungicides for control of Asian soybean rust in Attapulgus (Trial 3-CerexAgri-Nisso), Georgia. Plant Dis. Manag. Rep. 1:FC015. Online publication. doi:10/1094/FN61.

Kemerait, Jr. RC, Sconyers LE, Jost PH, Mills WA. 2006. Evaluation of fungicides for control of Asian soybean rust in Attapulgus (Valent Trial), Georgia, 2006. Plant Dis. Manag. Rep. 1:FC084. Online publication. doi:10.1094/FN61.

Kemerait, Jr. RC, Sconyers LE, Mills WA. 2006. Evaluation of fungicides for control of Asian soybean rust in Attapulgus (Trial 2-Dow), Georgia, 2006. Plant Dis. Manag. Rep. 1:FC082. Online publication. doi:10.1094/FN61.

Lawrence KS, Delaney MA, Sikora EJ, Delaney DP, Lawrence GW, Pegues M. 2006. Efficacy of foliar fungicides Punch and Charisma for Asian soybean rust disease management and yield enhancement in Alabama, 2006. Plant Dis. Manag. Rep. 1:FC042. Online publication. doi:10.1094/FN61.

Lawrence KS, Delaney MA, Sikora EJ, Delaney DP, Lawrence GW, Pegues M. 2007. Evaluation of Absolute, Folicur and Stratego on Asian soybean rust and yield in Alabama, 2006. Plant Dis. Manag. Rep. 1:FC078. Online publication. doi:10.1094/PDMR01.

Lawrence KS, Delaney MA, Sikora EJ, Delaney DP, Lawrence GW, Pegues M. 2007. Evaluation of selected fungicides for Asian soybean rust management and yield enhancement in Alabama, 2006. Plant Dis. Manag. Rep. 1:FC079. Online publication. doi:10.1094/PDMR01.

Lawrence KS, Sikora EJ, Delaney DP, Lawrence GW. 2013. Evaluation of Aproach Prima for control of soybean rust in south Alabama, 2013. Plant Dis. Manag. Rep. 8:FC224. Online publication. doi:10.1094/PDMR07.

Lawrence KS, Sikora EJ, Delaney DP, Lawrence GW, Pegues M. 2009. Evaluation of foliar fungicides for soybean rust management and yield in Alabama, 2008. Plant Dis. Manag. Rep. 3:FC029. Online publication. doi:10.1094/PDMR03.

Lawrence KS, Sikora EJ, Delaney DP, Nightengale SP. 2006. Evaluation of Absolute, Folicur and Stratego on soybean foliar disease and yield in Alabama, 2005. Fungicide and Nematicide Tests. Vol 61:FC030. Online publication. doi:10.1094/FN61.

Lawrence KS, Sikora EJ, Delaney DP, Nightengale SP. 2006. Evaluation of Punch, Charisma, Folicur, and Manzate on soybean foliar disease and yield in Alabama, 2005. Fungicide and Nematicide Tests. 61:FC029. Online publication. doi:10.1094/FN61.

Lawrence KS, Sikora EJ, Delaney DP, Pegues M. 2007. Evaluation of LEM17, Punch, and Headline for soybean rust management and yield in Alabama, 2007. Plant Dis. Manag. Rep. 2:FC052. Online publication. doi:10.1094/PDMR01.

Lawrence KS, Sikora EJ, Delaney DP, Pegues M. 2007. Evaluation of Topsin, Headline Tebuzol and ACT Plus on soybean rust and yield in Alabama, 2007. Plant Dis. Manag. Rep. 2:FC053. Online publication. doi:10.1094/PDMR01.

Lawrence KS, Sikora EJ, Delaney DP, Pegues M. 2008. Evaluation of Topsin on soybean rust and yield in Alabama, 2007. Plant Dis. Manag. Rep. 2:FC053. Online publication. doi:10.1094/PDMR02.

Lawrence KS, Sikora EJ, Delaney DP, Pegues, M. 2008. Soybean rust fungicide disease management and yield affects in Alabama, 2008. Plant Dis. Manag. Rep. 3:FC028. Online publication. doi:10.1094/PDMR03.

Mueller TA, Marois JJ, Wright DL. 2008a. Evaluation of Roundup WeatherMAX as a fungicide for the management of soybean rust at the NFREC, Quincy, FL, 2007. Plant Dis. Manag. Rep. 2:FC017. Online publication. doi:10.1094/PDMR02.

Mueller TA, Marois JJ, Wright DL. 2008b. Soybean rust control using single fungicide application at Quincy, FL 2007. Plant Dis. Manag. Rep. 2:FC023. Online publication. doi:10.1094/PDMR02. 
Mueller TA, Miles MR, Hartman GL. 2008. Evaluations of fungicides and fungicide timing for the control of soybean rust, Attapulgus, GA, 2006. Plant Dis. Manag. Rep. 2:FC044. Online publication. doi:10.1094/PDMR02.

Mueller TA, Miles MR, Hartman GL, O'Brien GK, Marois JJ, Wright DL. 2008. Evaluations of fungicides and fungicide timing for the control of soybean rust in northwest Florida, 2006. Plant Dis. Manag. Rep. 2:FC086. Online publication. doi:10.1094/PDMR02.

Mueller TA, O'Brien GK, Marois JJ, Wright DL. 2006. Evaluation of Cheminova fungicides for the management of soybean rust in northwest Florida, 2006. Plant Dis. Manag. Rep. 2:FC044. Online publication. doi:10.1094/FN06.

Mueller TA, O'Brien GK, Marois JJ, Wright DL. 2006. Evaluation of fungicides and adjuvants for the control of soybean rust in northwest Florida, 2006. Plant Dis. Manag. Rep. 2:FC085. Online publication. doi:10.1094/FN06.

Mueller TA, Obrien GK, Marois JJ, Wright DL. 2008. Evaluation of Cerexagri fungicides for the management of soybean rust in northwest Florida, 2006. Plant Dis. Manag. Rep. 2:FC089. Online publication. doi:10.1094/PDMR02.

Mueller TA, Obrien GK, Marois JJ, Wright DL. 2008. Evaluation of Dow fungicides for the management of soybean rust in northwest Florida, 2006. Plant Dis. Manag. Rep. 2:FC088. Online publication. doi:10.1094/PDMR02.

Mueller TA, Obrien GK, Marois JJ, Wright DL. 2008. Evaluation of fungicides for the control of soybean rust in northwest Florida, 2006. Plant Dis. Manag. Rep. 2:FC087. Online publication. doi:10.1094/PDMR02.

Mueller TA, Obrien GK, Marois JJ, Wright DL. 2008. Evaluation of Valent fungicides for the management of soybean rust in northwest Florida, 2006. Plant Dis. Manag. Rep. 2:FC090. Online publication. doi:10.1094/PDMR02.

O'Brien GK, Douglas MH, Marois JJ, Wright DL. 2013. Evaluation of fungicides for the control of soybean rust at the NFREC, Quincy, FL, 2012. Plant Dis. Manag. Rep. 7:FC054. Online publication. doi:10.1094/PDMR07.

O'Brien GK, George S, Douglas MH, Marois J.J, Wright DL. 2013. Evaluation of fungicides for the control of soybean rust at the NFREC, Quincy, FL, 2013. Plant Dis. Manag. Rep. 8:FC208. Online publication. doi:10.1094/PDMR07.

Padgett GB, Price JL, Hague S, Coco AB. 2001. The effect of fungicides on late season diseases of soybean, 2000. Fungicide and Nematicide Tests. 56:FC66. Online publication. doi:10.1094/FN56.

Padgett GB, Purvis MA. 2005a. Selected fungicide rates and timings for managing Cercospora foliar blight, 2005. Plant Dis. Manag. Rep. 61:FC043. Online publication. doi:10.1094/FN60.

Padgett GB, Purvis MA. 2005b. Selected fungicide rates and timings for managing Cercospora foliar blight and purple seed stain, 2005. Fungicide and Nematicide Tests Vol 61:044. Online publication. doi:10.1094/PDMR07.

Padgett GB, Purvis MA. 2007. Selected fungicide treatment for managing soybean rust and Cercospora foliar blight, 2007. Plant Dis. Manag. Rep. 2:FC046.

Price P, Padgett GB, Purvis MA. 2013. The effect of selected fungicides, application rates, and application timings to soybean, 2012. Plant Dis. Manag. Rep. 7:FC055. Online publication. doi:10.1094/PDMR07.

Schneider RW, Robertson CL, Giles CG, Mumma EP, Boudreaux JM, Griffin JL. 2006 Evaluations of various fungicides for the control of Asian Soybean rust, 2006. Plant Dis. Manag. Rep. 1:FC112. doi:10.1094/FN61.

Sikora EJ, Delaney MA, Delaney DP. 2013a. Evaluation of foliar applications of FORTIX for control of soybean rust, 2013. Plant Dis. Manag. Rep. 9:FC144. Online publication. doi:10.1094/PDMR09.

Sikora EJ, Delaney MA, Delaney DP. 2013b. Evaluation of foliar applications of Topguard SC for control of soybean rust, 2013. Plant Dis. Manag. Rep. 9:FC141. Online publication. doi:10.1094/PDMR09.

Sikora EJ, Delaney DP, Delaney MA, Lawrence KS, Pegues M. 2009. Evaluation of sequential fungicide spray programs for control of soybean rust. Plant Health Progress, 2: Apr 2009. 
Sikora EJ, Delaney MA, Delaney DP, Pegues M. 2008. Evaluation of Tebuzol to control Asian soybean rust and target spot in Alabama, 2007. Plant Dis. Manag. Rep. 2:FC110. Online publication. doi:10.1094/PDMR02.

Sikora EJ, Lawrence K, Delaney M, Delaney DP. 2012. Evaluation of Domark, Topguard and Topsin Xtra for control of Cercospora leaf blight on soybean, 2011. Plant Dis. Manag. Rep. 6:FC068. Online publication. doi:10.1094/PDMR06.

Sikora EJ, Lawrence K, Delaney M, Delaney DP. 2006. Evaluation of fungicide spray programs for Asian soybean rust, 2006. Plant Dis. Manag. Rep. 2:FC111. Online publication. doi:10.1094/FN61.

Sikora EJ, Lawrence K, Delaney M, Delaney DP, Pegues M. 2008. Evaluation of fungicides for control of Asian soybean rust and target spot in Alabama, 2006. Plant Dis. Manag. Rep. 2:FC109. Online publication. doi:10.1094/PDMR02.

Sikora, EJ, Lawrence KS, Gutierrez-Estrada A, Delaney DP, Durbin RM. 2005. Evaluation of Ballad for control of foliar diseases of soybean in Alabama, 2005. Fungicide and Nematicide Tests. 61:FC031. Online publication. doi:10.1094/FN61.

Sikora EJ, Lawrence KS, Gutierrez-Estrada A, Delaney DP, Pegues M. 2005. Evaluation of fungicide spray programs for Asian Soybean Rust in Alabama, 2005. Fungicide and Nematicide Tests Vol 61:FC032. Online publication. doi:10.1094/FN60.

\section{References}

1. Bromfield, K.R. Soybean rust. Monogr No. 11; American Phytopathological Society: St. Paul, MN, USA, 1984.

2. $\mathrm{CAB}$ International. Phakopsora pachyrhizi. In Invasive Species Compendium; CAB International: Wallingford, UK, 2018; Available online: www.cabi.org/isc/datasheet/40019 (accessed on 17 May 2018).

3. Hartman, G.L.; Wang, T.C.; Tschanz, A.T. Soybean rust development and the quantitative relationship between rust severity and soybean yield. Plant Dis. 1991, 75, 596-600. [CrossRef]

4. Miles, M.R.; Frederick, R.D.; Hartman, G.L. Soybean Rust: Is the US Soybean Crop at Risk? American Phytopathological Society: St. Paul, MN, USA, 2003.

5. Pivonia, S.; Yang, X.B.; Pan, Z. Assessment of epidemic potential of soybean rust in the United States. Plant Dis. 2005, 89, 678-682. [CrossRef]

6. Yorinori, J.T.; Paiva, W.M.; Frederick, R.D.; Costamilan, L.M.; Bertagnolli, P.F.; Hartman, G.E.; Godoy, C.V.; Nunes, J., Jr. Epidemics of soybean rust (Phakopsora pachyrhizi) in Brazil and Paraguay from 2001 to 2003. Plant Dis. 2005, 89, 675-677. [CrossRef]

7. Schneider, R.W.; Hollier, C.A.; Whitman, H.H.; Palm, M.E.; McKemy, J.M.; Hernandez, J.R.; Levy, L.; Devries-Patterson, R. First report of soybean rust caused by Phakopsora pachyrhiza in the Continental United States. Plant Dis. 2005, 89, 774. [CrossRef]

8. Allen, T.W.; Hollier, C.A.; Sikora, E.J. A continuing saga: soybean rust in the continental United States, 2004 to 2013. Outlooks Pest Manag. 2014, 25, 167-174. [CrossRef]

9. Sikora, E.J.; Delaney, D.P.; Delaney, M.A. Observations on soybean rust management in Alabama in 2012. In Proceedings of the Southern Soybean Disease Workers 40th Annual Meeting, Pensacola Beach, FL, USA, 13-14 March 2013.

10. Sikora, E.J.; Conner, K.; Delaney, D.; Zhang, L.; Delaney, M. Observations on soybean rust and soybean vein necrosis virus in Alabama in 2013. In Proceedings of the Southern Soybean Disease Workers 41st Annual Meeting, Pensacola Beach, FL, USA, 5-6 March 2014.

11. Alabama Cooperative Extension System. Making a Difference in Every Corner of the State. 2012 Annual Report, ACES-0001. 2013. Available online: http://www.aces.edu/pubs/docs/A/Aces-0001.pdf (accessed on 12 February 2014).

12. Sikora, E.J.; Delaney, D.P.; Delaney, M.A.; Lawrence, D.S.; Pegues, M. Evaluation of sequential fungicide spray programs for control of soybean rust. Plant Health Prog. 2009. [CrossRef]

13. Tenuta, A.; Hershman, D.; Draper, M.; Dorrance, A. Fungicide basics. In Using Foliar Fungicides to Manage Soybean Rust; SR-2005; Dorrance, A.E., Draper, M.A., Hershman, D.E., Eds.; Ohio State University: Columbus, OH, USA, 2008; pp. 22-29.

14. Schulze, R. Meta-Analysis: A Comparison of Approaches; Hogrefe and Huber: Cambridge, MA, USA, 2004. 
15. Shaw, D.V.; Larson, K.D. A meta-analysis of strawberry yield response to preplant soil fumigation with combinations of methyl bromide-chloropicrin and four alternative systems. HortScience 1999, 34, 839-845.

16. Dalla Lana, F.; Ziegelmann, P.K.; Maia, A.D.H.N.; Godoy, C.V.; Del Ponte, E.M. Meta-analysis of the relationship between crop yield and soybean rust severity. Phytopathology 2015, 105, 307-315. [CrossRef] [PubMed]

17. Scherm, H.; Christiano, R.S.C.; Esker, P.D.; Del Ponte, E.M.; Godoy, C.V. Quantitative review of fungicide efficacy trials for managing soybean rust in Brazil. Crop Prot. 2009, 28, 774-782. [CrossRef]

18. Shah, D.A.; Dillard, H.R. Yield loss in sweet corn caused by Puccinia sorghi: A meta-analysis. Plant Dis. 2006, 90, 1413-1418. [CrossRef]

19. A Language and Environment for Statistical Computing. R Foundation for Statistical Computing: Vienna, Austria, 2015. Available online: https: / www.R-project.org/ (accessed on 4 October 2016).

20. A Meta-Analysis Package for $\mathrm{R}++$ 2015, Version 1.9-8. Available online: http:/ / www.metafor-project.org (accessed on 4 October 2016).

21. Lajeunesse, M.J. Recovering missing or partial data from studies: a survey of conversions and imputations for meta-analysis. In Handbook of Meta-Analysis in Ecology and Evolution; Koricheva, J., Gurevitch, J., Mengersen, K., Eds.; Princeton University Press: Princeton, NJ, USA, 2013; pp. 195-206.

22. Adams, D.C.; Gurevitch, J.; Rosenberg, M.S. Resampling tests for meta-analysis of ecological data. Ecology 1997, 78, 1277-1283. [CrossRef]

23. Complete Data and Analysis for: Fungicide Effectiveness on Soybean Rust in the Southeastern United States 2004-2014: A Meta-Analysis. Available online: http:/ / doi.org/10.13020/D62P4F (accessed on 28 May 2018).

24. Sikora, E.J.; Allen, T.W.; Wise, K.A.; Bergstrom, G.; Bradley, C.A.; Bond, J.; Brown-Rytlewski, D.; Chilvers, M.; Damicone, J.; DeWolf, E.; et al. A coordinated effort to manage soybean rust in North America: A success story in soybean disease monitoring. Plant Dis. 2014, 98, 864-875. [CrossRef]

25. United States Department of Agriculture. Integrated Pest Management Information Platform for Extension and Education. Available online: https:/ / www.ipmpipe.com (accessed on 16 May 2018).

26. Koricheva, J.; Gurevitch, J.; Mengersen, K. Handbook of Meta-Analysis in Ecology and Evolution; Princeton University Press: Princeton, NJ, USA, 2013.

27. Jennions, M.D.; Møller, A.P. Relationships fade with time: A meta-analysis of temporal trends in publication in ecology and evolution. Proc. R. Soc. Lond. Ser. B 2002, 269, 43-48. [CrossRef] [PubMed]

28. Arnquist, G.; Wooster, D. Meta-analysis: Synthesizing research findings in ecology and evolution. Trends Ecol. Evol. 1995, 10, 236-240. [CrossRef]

29. Gurevitch, J.; Hedges, L.V. Statistical issues in meta-analyses. Ecology 1999, 80, 1142-1149. [CrossRef]

30. Borenstein, M.; Hedges, L.V.; Higgins, J.P.T.; Rothstein, H.R. Introduction to Meta-Analysis; John Wily \& Sons, Ltd.: West Sussex, UK, 2009; p. 278. 